\title{
ANTIOXIDANT ISOENZYME RESPONSES TO NICKEL-INDUCED STRESS IN TOBACCO CELL SUSPENSION CULTURE
}

\author{
Georgia Bertoni Pompeu; Priscila Lupino Gratão²; Victor Alexandre Vitorello ${ }^{3}$; Ricardo \\ Antunes Azevedo ${ }^{2 *}$ \\ ${ }^{1}$ USP/CENA - Lab. de Ecologia Aplicada, Av. Centenário, 303 - 13416-700 - Piracicaba, SP - Brasil. \\ ${ }^{2}$ USP/ESALQ - Depto. de Genética, C.P. 83 - 13418-900 - Piracicaba, SP - Brasil. \\ ${ }^{3}$ USP/CENA - Lab. de Biologia Celular e Molecular. \\ *Corresponding author <raazeved@esalq.usp.br>
}

\begin{abstract}
Exposure to nickel (Ni) at high concentrations can lead to production of reactive oxygen species (ROS) resulting in oxidative damage at the cellular level. We investigated the antioxidative responses of Nicotiana tabacum cv BY-2 cell suspension to Ni stress $\left(0.075\right.$ and $\left.0.75 \mathrm{mM} \mathrm{NiCl}_{2}\right)$ over a $72 \mathrm{~h}$ period with special attention to potential alterations in isoenzymes of superoxide dismutase (SOD), catalase (CAT) and glutathione reductase (GR). Two main SOD isoenzymes were observed, a Mn-SOD (band I) and a Fe-SOD (band II), as well as one CAT isoenzyme and four GR isoenzymes. Activity staining analysis revealed that CAT activity plays a major role in the early response to Niinduced oxidative stress, particularly when the Ni concentration used was low, whilst a specific GR isoenzyme appears to respond to the $\mathrm{Ni}$-induced oxidative stress when a much higher $\mathrm{Ni}$ concentration was used to induce the stress for the same period of treatment. These results illustrate the importance and advantages of determining individual isoenzyme activities.

Key words: antioxidant enzymes, catalase, nickel, superoxide dismutase
\end{abstract}

\section{RESPOSTADE ISOENZIMAS ANTIOXIDANTESAO ESTRESSE INDUZIDO POR NÍQUEL EM CULTURA DE CÉLULAS EMSUSPENSÃO DE FUMO}

\begin{abstract}
RESUMO: A exposição ao níquel (Ni), em altas concentrações, pode levar à produção de espécies reativas de oxigênio (EAOs), resultando em danos oxidativos em nível celular. Foram investigadas as respostas antioxidativas de células em suspensão do cultivar BY-2 de Nicotiana tabacum submetidas ao estresse por $\mathrm{Ni}\left(0.075\right.$ e $0.75 \mathrm{mM}$ de $\left.\mathrm{NiCl}_{2}\right)$ por $72 \mathrm{~h}$, com atenção especial às alterações potencias em isoenzimas de superóxido dismutase (SOD), catalase (CAT) e glutatione redutase (GR). Duas principais isoenzimas de SOD foram observadas, uma Mn-SOD (banda I) e outra Fe-SOD (banda II), bem como uma isoenzima CAT e quatro isoenzimas de GR. As análises revelaram que a atividade de CAT tem papel principal no momento inicial de resposta ao estresse oxidativo induzido por $\mathrm{Ni}$, particularmente, quando sua concentração foi mais baixa, enquanto uma isoenzima específica de GR parece responder a este estresse na concentração mais alta de $\mathrm{Ni}$, no mesmo período de tratamento. Os resultados ilustram a importância e as vantagens de se determinar a atividade de isoenzimas individuais.

Palavras-chave: enzimas antioxidantes, catalase, níquel, superóxido dismutase
\end{abstract}

\section{INTRODUCTION}

It has been widely reported, particularly in more recent years, the problems related to contamination of the environment with heavy metals. Such contamination is mainly due to anthropogenic activities (Gratão et al., 2005). As a consequence, several aspects of heavy metal research has gained importance and special attention, resulting in a several fold increase in papers published in the literature describing the effect of heavy metal-induced oxidative stress in plants, a trend that is being followed by the study of other important elements (Vitória et al., 2001; Garcia et al., 2006; Gomes-Júnior et al., 2006a, 2006b; Lea \& Azevedo, 2006; Gomes-Júnior et al., 2007; Lea \& Azevedo, 2007), the effect on ultrastructure alterations (Vitória et al., 2006) and other aspects involving techniques of phytoremediation and heavy metal-soil-plant 
interactions (Fontes \& Alleoni, 2006; Gonzaga et al., 2006; Mendes et al., 2006; Nascimento, 2006; Sonmez et al., 2006; Pereira et al., 2007).

Plant responses to heavy metal exposure varies depending on plant species, tissue, stage of development, metal concentration and type of metal, triggering a series of defence mechanisms which involve enzymatic and non-enzymatic components (Gratão et al., 2005). In addition to the use of plant seedlings or adult plants, another interesting approach has been the use of in vitro cell cultures (Gomes-Júnior et al., 2007), since some of these factors can be controlled better.

Most of the published reports have presented data on total enzyme activity and isoenzyme activity profiles using non-denaturing PAGE. Our group has concentrated on the study of antioxidant enzyme responses to several distinct heavy metals in a series of plant species. We now report the effect of $\mathrm{Ni}$ on the activity of three important antioxidant enzymes in tobacco cell suspension culture. Such a study allows the better understanding of specific isoenzyme responses which is not possible if only total enzyme activity is determined.

\section{MATERIAL AND METHODS}

Tobacco BY-2 (Nicotiana tabacum L. cv. Bright Yellow 2) cells were cultured as described by Vitorello \& Haug (1996). Cultures were grown in the dark on a refrigerated rotary shaker (MA830/A, MARCONI, Brazil) at $160 \mathrm{rpm}$ at $27^{\circ} \mathrm{C}$ and growth was evaluated by packed cell volume following centrifugation at $500 \mathrm{rpm}$ for $5 \mathrm{~min}$. BY-2 cells were maintained in liquid medium for seven days and $3 \mathrm{~mL}$ of cell inoculum were subcultured into new medium $(50 \mathrm{~mL})$. Two-day-old cell cultures (beginning of log phase of growth) were submitted to preliminary trials on the effect of several $\mathrm{NiCl}_{2}$ concentrations $(0,0.05,0.075$, $0.1,0.15,0.2,0.5,0.75,1$ and $2 \mathrm{mM}$ ) for up to $72 \mathrm{~h}$ (beginning of stationary phase). Two concentrations were chosen for the main experiments, $0.075 \mathrm{mM}$ $\mathrm{NiCl}_{2}$, which exhibited growth and cell viability levels similar to the control, and $0.75 \mathrm{mM} \mathrm{NiCl}_{2}$, which exhibited about half the growth and cell viability at $72 \mathrm{~h}$ of treatment when compared to the control (data not shown). Two-day-old cell cultures were submitted to the treatments and cells were harvested at different periods following exposure $(12,36$ and $72 \mathrm{~h})$, were suction-dried and weighed for cell mass determination and storage at $-80^{\circ} \mathrm{C}$ for further analyses.

The following steps were carried out at $4{ }^{\circ} \mathrm{C}$ unless stated otherwise. The BY-2 cells were homogenized (2:1 buffer volume: fr. wt) in a mortar with a pestle with $100 \mathrm{mM}$ potassium phosphate buffer $(\mathrm{pH}$
7.5) containing $1 \mathrm{mM}$ ethylene-diaminetetra-acetic acid (EDTA), 3 mM DL-dithiothreitol and 5\% (w/v) insoluble PVPP (Azevedo et al., 1998). The homogenate was centrifuged at 15,000 rpm for $30 \mathrm{~min}$ and the supernatant was kept stored in separate aliquots at $-80^{\circ} \mathrm{C}$, prior to non-denaturing PAGE and SOD, CAT and GR analyses.

SOD, CAT and GR non-denaturing PAGE activity determinations, electrophoresis buffers and gels, and SOD isoenzyme classification were carried out as described by Gomes-Júnior et al. (2007). Briefly, electrophoresis was carried out in $8 \%$ polyacrylamide nondenaturing gels and a constant current of $20 \mathrm{~mA} / \mathrm{gel}$ was applied for $8 \mathrm{~h}$ (CAT gel) or $4 \mathrm{~h}$ (SOD and GR gels) and the temperature maintained at $4{ }^{\circ} \mathrm{C}$. Equal amounts $(60 \mathrm{mg})$ of protein were loaded on to each gel lane.

Isoenzyme profiles were also subjected to a densitometric analysis for band intensity through the use of Kodak Digital Science - 1D - Image Analysis Software version 3.0.1. in a Power Look 1120 imagine system (Umax Technology, Texas, U.S.A).

Protein concentration for all samples was determined by the method of Bradford (1976) using bovine serum albumin as a standard in a Lambda 40 spectrophotometer (Perkin-Elmer Corporation, USA).

The experimental design was randomized with three replicates for each flask/treatment/time interval. The results of the densitometric analysis were expressed as mean of three independent replicates of CAT, GR and SOD for one of the experiments. The gel images shown are from one of the replicates.

\section{RESULTS AND DISCUSSION}

In this study, SOD, CAT and GR isoenzyme bands were observed following staining of native PAGE gels for enzyme activity of tobacco BY-2 cells subjected to Ni-induced oxidative stress (Figure 1). Band intensity changes were also assessed based on a densitometry analysis (Table 1). Tobacco BY-2 cell cultures revealed two SOD, four GR and one CAT isoenzymes (Figure 1). SOD bands were classified, according to the inhibition patterns to hydrogen peroxide and $\mathrm{KCN}$, as Mn-SOD (SOD I - resistant to both inhibitors) and Fe-SOD (SOD II - inactivated by one of the inhibitors) (Figure 2), which have been shown to be located in distinct cell compartments in plants species. The tobacco SOD I is likely to be located in the mitochondria whereas SOD II in the plastid.

SOD activity staining did not reveal any specific isoenzyme alteration, but there were changes in activity, particularly at $36 \mathrm{~h}$ of exposure to $0.075 \mathrm{mM}$ $\mathrm{NiCl}_{2}$ when both SOD bands exhibited increases in ac- 
Table 1 - SOD, CAT and GR densitometry analysis of non-denaturing PAGE presented in Figure 1. The pixel intensity of each band was used to calculate the relative change (\%) with respect to the control (zero Ni) of each exposure period.

\begin{tabular}{lccccccc}
\hline & \multicolumn{3}{c}{$0.075 \mathrm{mM} \mathrm{NiCl}$} & & & \multicolumn{3}{c}{$0.75 \mathrm{mM} \mathrm{NiCl}_{2}$} \\
\cline { 2 - 5 } \cline { 7 - 8 } Isoenzyme & $12 \mathrm{~h}$ & $36 \mathrm{~h}$ & $72 \mathrm{~h}$ & & $12 \mathrm{~h}$ & $36 \mathrm{~h}$ & $72 \mathrm{~h}$ \\
\hline SOD I & 1.45 & 92.31 & -2.5 & & 1.67 & -9.59 & 1.91 \\
SOD II & 5.09 & 78 & 3.56 & & 2.56 & 1.95 & -2.8 \\
\hline CAT I & 40.36 & 59.35 & $*$ & & -39.18 & -41.9 & $*$ \\
\hline GR I & $*$ & $*$ & & & $*$ & $*$ & -3.70 \\
GR II & $*$ & $*$ & $*$ & & $* *$ & $* *$ & $*$ \\
GR III & 2.41 & -3.27 & -4.36 & & 1.90 & 1.85 & -3.42 \\
GR IV & -4.65 & -1.15 & -4.93 & & 5.75 & -1.12 & -6.43 \\
\hline
\end{tabular}

*band not was identified and **band was identified.

(A)

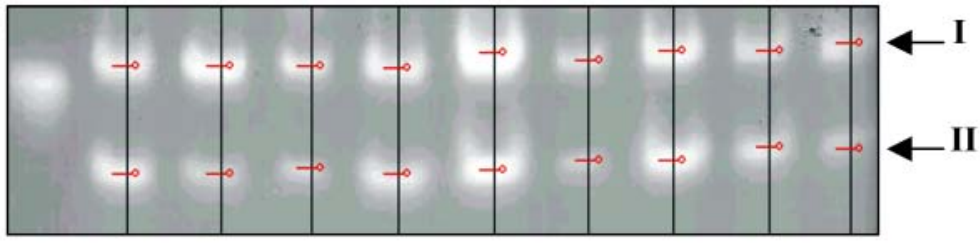

(B)

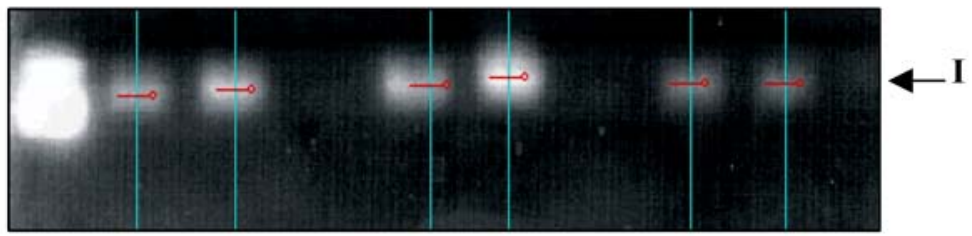

(C)

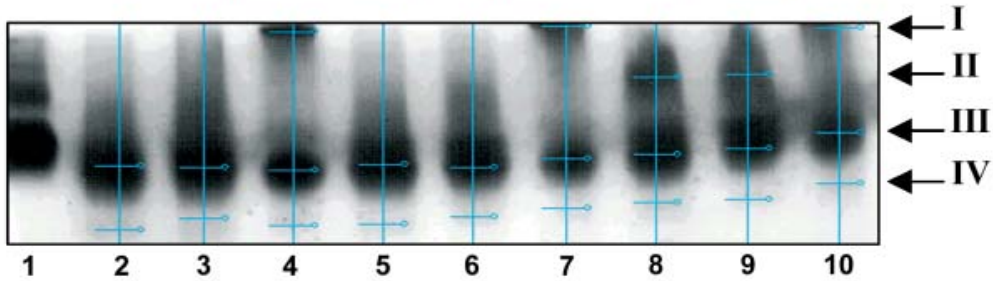

Figure 1 - Activity staining for (A) superoxide dismutase (SOD), (B) catalase (CAT) and (C) glutathione reductase (GR) following nondenaturing PAGE of extracts of tobacco BY-2 cells. Lane 1, bovine SOD, bovine liver CAT and Saccharomyces cerevisiae GR standards for (A), (B) and (C), respectively; lane 2, control (zero Ni), $12 \mathrm{~h}$; lane 3, control, $36 \mathrm{~h}$; lane 4, control $72 \mathrm{~h}$; lane 5, $0.075 \mathrm{mM} \mathrm{NiCl}_{2}, 12 \mathrm{~h}$; lane 6, $0.075 \mathrm{mM} \mathrm{NiCl}_{2} 36 \mathrm{~h}$; lane 7, $0.075 \mathrm{mM} \mathrm{NiCl}_{2}, 72 \mathrm{~h}$; lane 8, $0.75 \mathrm{mM} \mathrm{NiCl}_{2}, 12 \mathrm{~h} ; 1$ lane $9,0.75$ $\mathrm{mM} \mathrm{NiCl} 2,36 \mathrm{~h}$; lane $10,0.75 \mathrm{mM} \mathrm{NiCl}_{2}, 72 \mathrm{~h}$.

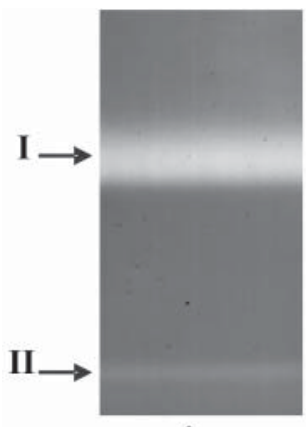

1

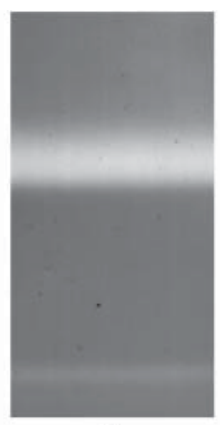

2

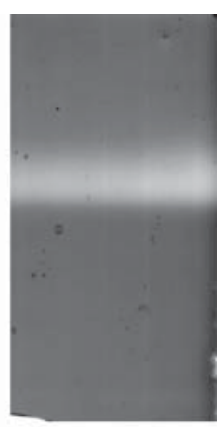

3
Figure 2 - SOD isoenzyme classification of tobacco BY-2 cell cultures. Lane 1, control SOD activity; lane 2, plus $2 \mathrm{mM}$ potassium cyanide and lane 3 , plus $5 \mathrm{mM}$ hydrogen peroxide. tivity. Apart from these increases, SOD activity was very similar to control levels in both concentrations tested (Figure 1A). SOD is widely distributed among $\mathrm{O}_{2}$-consuming organisms and is responsible for the dismutation of $\mathrm{O}_{2}{ }^{-}$into $\mathrm{H}_{2} \mathrm{O}_{2}$, and therefore influencing the concentration of $\mathrm{O}_{2}{ }^{\circ-}$ and $\mathrm{H}_{2} \mathrm{O}_{2}$. SOD isoenzymes are compartmentalized in higher plants and three isoenzymes have been detected in plants, which are classified according to their metal cofactor; $\mathrm{Mn}, \mathrm{Fe}$ and $\mathrm{Cu} / \mathrm{Zn}$ (Gratão et al., 2005). Mn-SODs are located in the mitochondria and peroxisomes, $\mathrm{Fe}$-SOD has been shown to be associated with the chloroplasts (Gratão et al., 2005), while the Cu/Zn-SODs are located in the cytosol, chloroplasts and peroxisomes (Gratão et al., 2005). SOD activity responses to Ni 
stress have been shown to vary considerably depending on plant species, tissue and duration of exposure. We identified and classified two SOD isoenzymes in BY-2 cells, Mn-SOD and Fe-SOD, but up to nine SOD isoforms have been reported in cell suspension cultures of $C$. arabica, two bands corresponding to Mn-SOD and three bands to Fe-SOD isoenzymes (Gomes-Júnior et al., 2006a, 2006b, 2007).

CAT activity staining (Figure 1B) revealed only one CAT isoenzyme in BY-2 cell culture, which was also shown to vary in response to $\mathrm{NiCl}_{2}$, exhibiting an increase in activity in the $0.075 \mathrm{mM} \mathrm{NiCl}_{2}$ treatment at $6 \mathrm{~h}$ and $36 \mathrm{~h}$ of treatment, whereas in the $0.75 \mathrm{NiCl}_{2}$ treatment CAT activity was reduced when compared to their respective controls. Interestingly, no CAT activity was detected at $72 \mathrm{~h}$ in both control and $\mathrm{Ni}$ treatments (Figure 1B). More than one CAT isoenzyme is normally observed in plant species (Azevedo et al., 1998), however, in the present study only one major CAT isoenzyme could be detected following non-denaturing PAGE activity staining. CAT is directly regulated by $\mathrm{H}_{2} \mathrm{O}_{2}$ levels and the increase in CAT activity particularly during the first $36 \mathrm{~h}$ of $\mathrm{Ni}$ treatment indicates that CAT is possibly acting in the dismutation of the excess $\mathrm{H}_{2} \mathrm{O}_{2}$ produced as a result of the $\mathrm{Ni}$-induced oxidative stress. Nevertheless the participation of other peroxidases to dismutate the $\mathrm{H}_{2} \mathrm{O}_{2}$ cannot be ruled out, particularly in the highest $\mathrm{NiCl}_{2}$ concentration tested, since CAT activity was even slightly reduced when compared to the controls.

The possibility of other enzymes being involved in the response to Ni stress under certain concentrations or periods of treatment was further confirmed by the results observed for GR activity (Figure 1C). Overall, GR activity did not vary much since the isoenzymes III and IV, which accounted for the majority of GR activity, exhibited similar levels of activities among Ni concentrations and controls during the duration of the experiment, however, GR I only appeared after $72 \mathrm{~h}$ treatment, but not as a response to $\mathrm{Ni}$-induced stress, since this isoenzyme was also observed in the control at $72 \mathrm{~h}$ (Figure 1C). On the other hand, the appearance of GR II isoenzyme at 12 $\mathrm{h}$ and $36 \mathrm{~h}$ of $0.75 \mathrm{mM} \mathrm{NiCl}$ treatments is clearly due to the Ni-induced oxidative stress, confirming the importance of non-denaturing PAGE analysis in the identification of such specific changes. In plants, cytosolic and plastidic GR isoenzymes have been identified (Xiang \& Oliver, 1998), however in BY-2 cells cytosolic GR isoenzymes are likely to be predominant since the cells were grown in the dark. Although these cells contain numerous plastids, antioxidant activity is expected to be low, since no photochemical reactions are occurring.
In conclusion, differential responses by SOD, CAT and mainly GR isoenzymes may be correlated to specific cell physiological phenomena due to the specific organelle localization of the isoenzymes. It appears that CAT has a major role in dismutating $\mathrm{H}_{2} \mathrm{O}_{2}$ produced in low Ni concentrations, whereas GR and even other peroxidases take over the process and have a more important role when high concentrations of $\mathrm{Ni}$ are used, leading to a more severe and faster establishment of oxidative stress.

\section{ACKNOWLEDGEMENTS}

This work was funded by Fundação de Amparo à Pesquisa do Estado de São Paulo (FAPESP - Grant n $\left.{ }^{\circ} .04 / 08444-6\right)$. R.A.A., G.B.P. and P.L.G. would like to thank CNPq for the fellowship and scholarship granted.

\section{REFERENCES}

AZEVEDO, R.A.; ALAS, R.M.; SMITH, R.J.; LEA, P.J. Response of antioxidant enzymes to transfer from elevated carbon dioxide to air and ozone fumigation, in the leaves and roots of wildtype and a catalase-deficient mutant of barley. Physiologia Plantarum, v.104, p.280-292, 1998.

BRADFORD, M.M. A rapid and sensitive method for the quantification of microgram quantities of protein utilizing the principle of protein-dye binding. Analytical Biochemistry, v.72, p.248-254, 1976.

FONTES, M.P.F.; ALLEONI, L.R.F. Electrochemical attributes and availability of nutrients, toxic elements, and heavy metals in tropical soils. Scientia Agricola, v.63, p.589-608, 2006.

GARCIA, J.S.; GRATÃO, P.L.; AZEVEDO, R.A.; ARRUDA, M.A.Z. Metal contamination effects on sunflower (Helianthus annuus L.) growth and protein expression in leaves during development. Journal of Agricultural and Food Chemistry, v.54, p.8623$8630,2006$.

GOMES-JÚNIOR, R.A.; MOLDES, C.A.; DELITE, F.S.; GRATÃO, P.L.; MAZZAFERA, P.; LEA, P.J.; AZEVEDO, R.A. Nickel elicits a fast antioxidant response in Coffea arabica cells. Plant Physiology and Biochemistry, v.44, p.420-429, 2006 a.

GOMES-JÚNIOR, R.A.; MOLDES, C.A.; DELITE, F.S.; POMPEU, G.B.; GRATÃO, P.L.; MAZZAFERA, P.; LEA, P.J.; AZEVEDO, R.A. Antioxidant metabolism of coffee cell suspension cultures in response to cadmium. Chemosphere, v.65, p.1330-1337, 2006 b.

GOMES-JÚNIOR, R.A.; GRATÃO, P.L.; GAZIOLA, S.A.; MAZZAFERA, P.; LEA, P.J.; AZEVEDO, R.A. Selenium-induced oxidative stress in coffee cell suspension cultures. Functional Plant Biology, v.34, p.449-456, 2007.

GONZAGA, M.I.S.; SANTOS, J.A.G.; MA, L.Q. Arsenic phytoextraction and hyperaccumulation by fern species. Scientia Agricola, v.63, p.90-101, 2006.

GRATÃO, P.L.; POLLE, A.; LEA, P.J.; AZEVEDO, R.A. Making the life of heavy metal-stressed plants a little easier. Functional Plant Biology, v.32, p.481-494, 2005.

LEA, P.J.; AZEVEDO, R.A. Nitrogen use efficiency. I. Uptake of nitrogen from the soil. Annals of Applied Biology, v.149, p. 243-247, 2006.

LEA, P.J.; AZEVEDO, R.A. Nitrogen use efficiency. II. Amino acid metabolism. Annals of Applied Biology, v.151, p.269$275,2007$. 
MENDES, A.M.S.; DUDA, G.P.; NASCIMENTO, C.W.A.; SILVA, M.O. bioavailability of cadmium and lead in a soil amended with phosphorous fertilizers. Scientia Agricola, v.63, p.328-332, 2006.

NASCIMENTO, C.W.A. Organic acids effects on desorption of heavy metals from a contaminated soil. Scientia Agricola, v.63, p.276-280, 2006.

PEREIRA, B.F.F.; ABREU, C.A.; ROMEIRO, S.; LAGOA, A.M.M.A.; PAZ-GONZALEZ, A. Pb-phytoextraction by maize in a Pb-EDTA treated oxisol. Scientia Agricola, v.64, p.52$60,2007$.

SONMEZ, S.; KAPLAN, M.; SONMEZ, N.K.; KAYA, H.; UZ, I. High level of copper application to soil and leaves reduce the growth and yield of tomato plants. Scientia Agricola, v.63, p.213-218, 2006.

VITORELLO, V.A.; HAUG, A. Short-term aluminum uptake by tobacco cells: growth dependence and evidence for internalization in a discrete peripheral region. Physiologia Plantarum, v.97, p.536-544, 1996.
VITÓRIA, A.P.; DA CUNHA, M.; AZEVEDO, R.A. Ultrastructural changes of radish leaf exposed to cadmium. Environmental and Experimental Botany, v.58, p.47-52, 2006.

VITÓRIA, A.P.; LEA, P.J.; AZEVEDO, R.A. Antioxidant enzymes responses to cadmium in radish tissues. Phytochemistry, v.57, p.701-710, 2001 .

XIANG, C.; OLIVER, D.J. Glutathione metabolic genes coordinately respond to heavy metals and jasmonic acid in Arabidopsis. Plant Cell, v.10, p.1539-1550, 1998.

Received October 10, 2007

Accepted May 30, 2008 